\title{
Analysis of Financing Plan for Real Estate Development Project
}

\author{
Tingting Wu \\ Office of Facility Service and Campus Development, Beijing International Studies University, Beijing, China \\ Email: wutingting@bisu.edu.cn
}

How to cite this paper: $\mathrm{Wu}$, T.T. (2019) Analysis of Financing Plan for Real Estate Development Project. Open Journal of Business and Management, 7, 1338-1345. https://doi.org/10.4236/ojbm.2019.73092

Received: June 14, 2019

Accepted: July 16, 2019

Published: July 19, 2019

Copyright $\odot 2019$ by author(s) and Scientific Research Publishing Inc. This work is licensed under the Creative Commons Attribution International License (CC BY 4.0).

http://creativecommons.org/licenses/by/4.0/

\begin{abstract}
Financing plan plays a key role in prophase plan of real estate development project, which attempts to find and decide the optimal scheme to offer enough capital in the real estate development. This paper firstly conducts a comparative analysis of different financing channels, then aiming at the disadvantages in real estate financing practice; the concrete improved thinking is posed. Furthermore, based on the features of financing demand in different phases of real estate development, financing procedure and methods are thoroughly analyzed to demonstrate in detail how to draw out a rational financing plan with the integrated application of diversified financing channels.
\end{abstract}

\section{Keywords}

Real Estate Development, Financing Plan, Financing Channels

\section{Introduction}

Up to now, real estate developers raise most capital from commercial banks, while other financing channels like Stocks, Bond and Trusts are of small proportion. Diversified financial support system has yet to be formed. Statistics show that commercial banks take up more than half the financing burden in total. The real estate enterprises suffer a lot from their over-dependence on the bank loans: lack of financing channels, soft budget constraint and high debt ratio. Additionally, with a series of policies for regulating the real estate market coming into effect along with the "document No. 195" and the "document No. 121" put out by Central Bank, the commercial banks have all enhanced the standard of loans, greatly increasing the loan difficulty of developers; thus great fund shortages are facing the real estate development.

Drawing up a scientific and rational financing plan with the application of di- 
versified financing channels could solve the problem effectively. Financing plan is quite needed and made an important component in a project's prophase programming, and plays a key role in capital-controlling during the development period. A considerable amount of research has been undertaken on respective financing channels, but fewer studies are devoted to their integrated application as the whole financing program. So the crucial task of developers is to seek diversified financing channels and make the optimal financing plan so as to avoid the risks and fund shortages as possible in real estate development [1].

\section{Analysis of Existing Financing Channels}

A single financing channel is not fit for the whole development period or for all enterprises, because different financing tools may differ in several aspects such as policy limitation, risk, profit and cost. It's necessary to make a comprehensive view upon them firstly.

\subsection{Bank Loans}

Loaning from banks has always been the chief way in real estate financing. From the perspective of internal structure of loans in real estate enterprises, bank loans mainly consist of developers' loan and individual housing mortgage loan. Compared with other financing channels, the loan term is relatively short and the loan amounts relatively small. Small-sized real estate enterprises, especially those in the start-up stage and lack of good credit history, obtain the loans difficultly from the banks, so broadening financing channels becomes a superior choice for them. But bank loans would still be the most primary financing channel for all the real estate enterprises in a long period of time [2].

\subsection{Cooperative Development}

It is a real estate developing way as well as a financing way. The developers who lack owned capital could cooperate with those having land reserve, or can they cooperate with the operators like construction enterprises, so as to get stable cash inflow from the shared resource and effectively avoid operating risks. As for medium-sized real estate enterprises, cooperative development can ensure the intact of capital chain and smooth financing under the situation of loan difficulty.

\subsection{Stocks}

It is very popular to permit qualified enterprises to finance on the stock market. Issuing shares is advantageous to reduce the debt ratio and to disperse the investment risk to the public, and is particularly favorable to raise massive funds in a short period of time. Every coin has two sides. This mode takes very strict conditions, quite long time, complicated procedure as well as high cost as its symbol, therefore very few real estate enterprises are qualified to go public and issue shares. 


\subsection{Bond}

Issuing real estate bonds as a mode to raise money can prevent to disperse control power, and it's more flexible by contrast with issuing shares, but without corresponding legal circumstance, real estate bonds market doesn't develop fully under the policy of interest rate control. There are only a few kinds of real estate bonds in China.

Compared with real estate bonds, short-term bond develops with a high speed since it's firstly issued in May, 2005. Short-term bond is favorable for its flexible interest rate and term, high turnover speed and low cost. It's more widely used than real estate bonds in real estate development.

\subsection{Real Estate Investment Trusts}

Real estate investment trusts, REIT for short, is a new method of financing. The outstanding features of REITS are the lower financing cost and higher illiquidity, and the profit level is stable and the market return is comparatively high. For some real estate development projects whose owned capital input is not enough and fail to meet the conditions in loaning from banks, this kind of method is well worth applying [3]. Thus, in contrast with the single project limitation of traditional real estate enterprises, it enables them invest two or more projects at the same time, which in turn enhance the risk-avoiding capability.

\section{Improvement to Existing Financing Plan}

In real estate financing practice, financing strategies are usually decided by the developers' experiences, with certain blindness and unreasonableness. The existing financing plan of real estate project could be improved in following aspects:

1) Improve the analysis of capital flow of the project. The capital flow varies greatly due to different phases in the development period and reflects the corresponding financing demand. Different financing channels may suit to different financing demand, and so a diversified financing mode can be set up based on the selection of financing channels in respective phase.

2) Improve the combination of long-term and short-term financing. When market demand has risen, the use of flexible short-term financing methods can help grasp marketing opportunities and increase profits. While in slump of sales the long-term financing channels are advantageous to overcome the debt-paying risks.

3) Improve the combination of equity and debt financing. This ensures the developers can take full advantage of the low cost of debt capital and raise the rate of return on owned capital in a good marketing prospect. This also guards against heavy debt burden in slump of sales.

\section{A Designing on Financing Plan of Real Estate Development Project}

Only the residential real estate's financing procedure and methods are to be illu- 
strated here.

\subsection{Capital Demand and Payment Estimation}

Estimation on the development cost is the first step and essential to the analysis of capital demand. Generally, the development cost of a real estate project consists of the following items (see Table 1 ).

The corresponding payment plan is made according to the acquirement of land, construction scheduled plan, negotiations with contractors and some specific payment terms. Please find in the following the terms of payment for the items listed in Table 1.

The land cost shall be paid by installments with terms determined by negotiations with land holders.

With smaller amount and similar terms of payment, the cost in initial \& final stage will be put together with the engineering cost in construction stage. The effect caused by different terms of payment shall be taken into consideration, such as the advance payment, contractors' advanced funds and methods of accounts settlement (time based or progress based). Furthermore, as Principal Contractor, the real estate developer holds a position of advantage during the negotiations with construction enterprises and can propose to defer some payment until the completion of the project.

The management and selling expenses shall be paid according to the development and sales progress; Financial charges, i.e. the interests on loan shall be paid according to the amount of loan and credit repayment program; In financing practice for current real estate projects most of the enterprises deduct sales tax and income tax from the sales revenue, failing to consider the point of time for tax payment.

Table 1. Components of development cost for real estate project.

\begin{tabular}{|c|c|c|c|}
\hline \multicolumn{2}{|c|}{ Items of development cost } & Detailed composition & Remarks \\
\hline \multicolumn{2}{|l|}{ Land cost } & $\begin{array}{l}\text { Remuneration for assignment of the right to the use of land, } \\
\text { compensation fees of the land requisition or removal, } \\
\text { relocation compensation fees, stipulated fees, etc. }\end{array}$ & $\begin{array}{l}\text { Accounting for } 20 \% \text { to } 30 \% \text { of the } \\
\text { gross investment. The proportion } \\
\text { varies due to different land type, plot } \\
\text { ratio and land use type. }\end{array}$ \\
\hline \multicolumn{2}{|c|}{$\begin{array}{l}\text { Engineering cost in } \\
\text { construction stage }\end{array}$} & $\begin{array}{l}\text { Equipment procurement cost; construction and installation cost, } \\
\text { supervision cost, etc. }\end{array}$ & $\begin{array}{l}\text { Accounting for about half the gross } \\
\text { investment. }\end{array}$ \\
\hline \multicolumn{2}{|c|}{$\begin{array}{l}\text { Engineering cost in } \\
\text { initial \& final stage }\end{array}$} & $\begin{array}{l}\text { Cost of planning, design, feasibility and hydrogeologic survey, } \\
\text { cost of "Three connections and one leveling", cost of } \\
\text { infrastructure and supporting facilities construction, etc. }\end{array}$ & $\begin{array}{l}\text { Accounting for } 5 \% \text { to } 10 \% \text { of the } \\
\text { gross investment. }\end{array}$ \\
\hline \multirow{5}{*}{$\begin{array}{l}\text { Other } \\
\text { expenses } \\
\text { related to } \\
\text { development }\end{array}$} & $\begin{array}{l}\text { Management } \\
\text { expenses }\end{array}$ & $\begin{array}{l}\text { Wages and welfare expenses, office expenses, labor protection } \\
\text { fees, expenses on water and electricity, etc. }\end{array}$ & \multirow{5}{*}{$\begin{array}{l}\text { Accounting for } 5 \% \text { to } 10 \% \text { of the } \\
\text { gross investment. }\end{array}$} \\
\hline & Financial charges & Loan interests and other expenses in financing & \\
\hline & Selling expenses & $\begin{array}{l}\text { Fees for advertising and exhibitions, sales } \\
\text { mechanism expenses, etc. }\end{array}$ & \\
\hline & Taxes & \multirow[t]{2}{*}{ Increment tax on land value, deed tax, sales tax; income tax, etc. } & \\
\hline & Contingencies & & \\
\hline
\end{tabular}




\subsection{Capital Inflow and Income Estimation}

The developers get back capital by selling real estate. Advance sale enables selling and capital flow-back ahead of the project complement. Accurate sales income estimation is necessary to its successful collection, which accounts for most of the capital inflow during the development period. To do this, a practical marketing program (Incl. type of housing for rent or sale, time, quantity, area, price and terms of payment) as well as a reliable and favorable collection plan (Incl. the number and percentage of installments) shall be made based on the adequate market forecasts and in accord with relevant laws and regulations in real estate industry, and then a corresponding income-flow table can be drafted [4].

It is worth noting that the advance sale can hardly be carried out successfully without the support of individual housing mortgage loan. According to the "document No. 195", developers can get mortgage loans from commercial banks only after the roof-sealing of main body in tier building or two-thirds of the gross investment has completed in high-rise building. So the point of time when mortgage loans can be granted for the two types of building should be calculated respectively in the income-flow table.

\subsection{Financing Demand Analysis}

Based on the above payment plan and income estimation, financing demand during the real estate development period can be calculated accordingly, which is essential in selecting the corresponding financing channels.

The financing demand is caused by the balance between the capital demand and the owned capital. As shown in Figure 1, the investment curve indicates the time-scaled capital demand while the sales income curve shows the income flow whose profits turn into owned capital. The vertical spacing between the two curves at a same point of time represents the fund gap, amounting to the net financing demand of the project at that time. The intersection point of the two curves shows that at this very time point the sales income covers exactly the development cost, and no more short-term financing is needed from this point of time.

\subsection{The Selection of Corresponding Financing Channels and Financing Mode Set-up}

The development period could be divided into mainly three phases: the preparation, construction and marketing phase, and financing demand varies greatly due to respective phases. Based on the characteristics of financing demand in different phases, the appropriate financing channels can be selected correspondingly and then the diversified financing mode be set up.

1) Preparation phase: long-term equity financing channels

In this phase, Land cost accounts for the greatest proportion of the gross investment. The risks facing the real estate enterprises are mainly the insufficient 


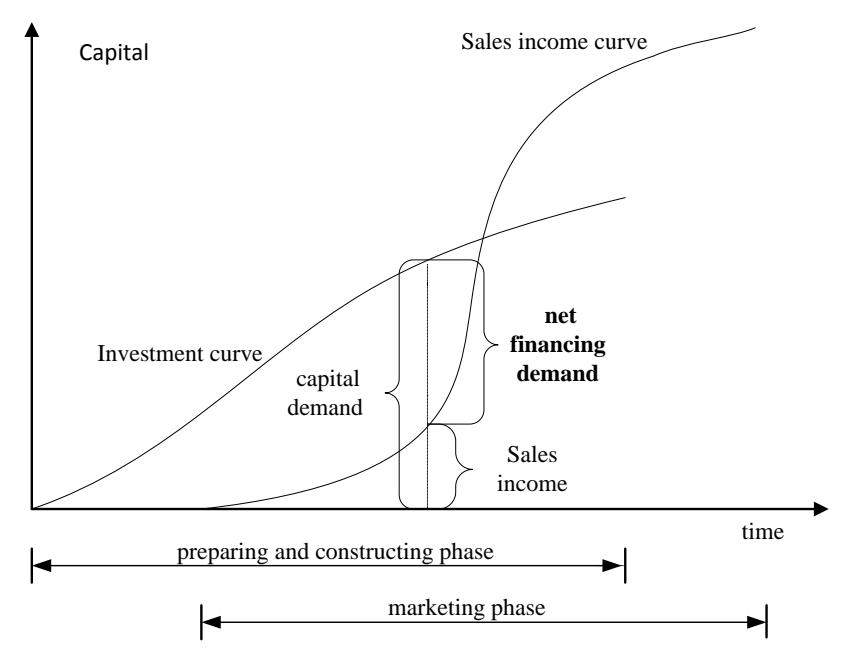

Figure 1. Net financing demand during real estate development.

investment budget. Because of the long occupation of capital and large amount of capital needed, as well as the requirement of owned capital accounting for at least 30\% for loaning, the long-term equity financing channels can be accepted in preparation phase. As a continuous investment for all real estate enterprises, land cost needs the longest financing period, and can hardly be supported by debt financing methods. Banks loan may not suit for this phase. Because of its relatively short term, the continuity of loan is not assured and huge debt-paying risk exists. As for the large real estate enterprises, REITS and owned capital who comes from the corporate profits accumulation are worthy of considering, which would effectively lower the debt-paying risk. For the small and medium-sized enterprises, aiming at adding to owned capital and avoiding policy limitation, they can choose cooperative development to get stable cash inflow.

2) Construction phase: short-term debt financing channels

Development cost in this phase mainly includes equipment and raw materials procurement cost, construction and installation cost, and the cost of supporting facilities construction. The above cost and expenses pose the short-term fluctuations in capital flow, thus short-term financing methods can be adopted. Bank loans become the first choice in this phase. Issuing bonds, with less policy limitation and the continuity of capital as well as low cost, is suitable in this phase, too. Short-term bond is an ideal choice in the middle of construction phase and marketing phase for the developers with good credit.

3) Marketing phase: short-term equity financing channels

When the project's advance sale begins, the sales income becomes the main capital resource. After the roof-sealing of main body in tier building or two-thirds of the gross investment has completed in high-rise building, housing mortgage loans can be granted to supply financial support to the house purchasers. The application of mortgage loans could expand the sale range and increase the sales income, and ensure a stable and continuous flow-back of capital, helping the developer to cover the expenses in final stage and take back the part or all initial 
investment quickly [5]. The developer even could earn the profit in a short period. Therefore, sales income supported by housing mortgage loans is suitable for marketing phase.

Based on the above analysis, we propose a financing mode to show the application of diversified financing channels in a real estate development project (see Table 2).

\subsection{Financing Plan Arrangement in Detail}

A comprehensive and detailed financing plan can be made based on the integrated application of the selected financing channels to meet varied financing need.

As per the above-mentioned methods, land cost shall be paid by the developers' right and equity capital with terms determined by negotiations with land holders. Installments payment is applied more often than single payment. While the owned capital from corporate profit accumulation is not that enough, REITS is apparently a suitable solution for almost all types of real estate enterprises to raise the right and equity capital. The capital of REITS has high illiquidity, which suits exactly for the land cost and meets the requirement of high proportion of equity funds, and prepares the developers well to loan from banks in the next step.

Capital is in continuously need along with the land developing and construction working in progress. Before obtaining "four certifications" of the project, and without the loans from banks, the initial development cost and expenses shall be paid by the developers with their owned capital or by the contractors with advanced funds. With the acquisition of "four certifications" upon the land cost paid up, developers can apply for development loans from commercial banks for special use in construction.

The toughest time for developers may be the period before "roof-sealing" or $2 / 3$ of the gross investment completed. In this period, although developers have got the sales permit and advance sale for the project begins, actually, the deals can hardly be made without the support of housing mortgage loans. At the same time, the construction work is in progress and large amount of capital still

Table 2. Financing mode of diversified financing channels.

\begin{tabular}{|c|c|c|c|}
\hline & Preparation phase & Construction phase & Marketing phase \\
\hline Works & $\begin{array}{l}\text { Land requisition } \\
\text { Preliminary development }\end{array}$ & Construction and installation & $\begin{array}{l}\text { Advance selling } \\
\text { Project complement }\end{array}$ \\
\hline Capital demand & $\begin{array}{l}\text { Land cost } \\
\text { Initial development cost }\end{array}$ & $\begin{array}{l}\text { Cost and expenses in } \\
\text { construction and installation }\end{array}$ & $\begin{array}{l}\text { Relevant financial charges } \\
\text { Selling expenses } \\
\text { Taxes }\end{array}$ \\
\hline $\begin{array}{l}\text { Characteristics of } \\
\text { financing demand }\end{array}$ & Long-term equity financing & Short-term debt financing & Short-term equity financing \\
\hline $\begin{array}{l}\text { Corresponding } \\
\text { financing channels }\end{array}$ & $\begin{array}{l}\text { Equity funds } \\
\text { REITS }\end{array}$ & $\begin{array}{l}\text { Bank loans } \\
\text { Issuing short-term bonds }\end{array}$ & $\begin{array}{l}\text { Sales income (supported by housing } \\
\text { mortgage loans) }\end{array}$ \\
\hline
\end{tabular}


needed. Thus the developers are faced with fund shortages. To solve this problem, the developers' subsidizing-interest-entrusting-loan can be applied to supply financial support to the house purchasers. It functions as the substitute of mortgage loan but enables sales in advance, so as to make up the broken consumption before the "roof-sealing" and ensure a stable and continuous flow-back of capital. Then the sales income could be used as circulating funds to repay the expired bank loans. Besides, short-term bond is another ideal choice in the middle of construction phase and marketing phase for developers especially those with good credit.

At roof-sealing or when $2 / 3$ of the gross investment has completed, the developers can get mortgage for individual housing lending from the commercial banks, replacing the developers' subsidizing-interest-entrusting-loan. The sales income increases stably. The rest of construction cost, expired development loans and relevant financial charges, selling expenses as well as taxes, etc. could be solved by sales income.

\section{Conclusion}

A rational financing plan is quite needed and made an important component in a project's prophase programming. This paper is for seeking effective financing plan for real estate development project to assure the smoothness and continuity of the capital flow and avoid fund shortages as best as it can. The key point is to make financing channels diversified. The designing of a financing plan requires firstly estimation on the financing demand in different phases of the project. Then, with appropriate structure of long-term, short-term, equity and debt financing determined based on the above estimation, corresponding financing channels can be selected and suited financing strategies be applied, and then a financing plan of diversified channels is reasonably arranged.

\section{Conflicts of Interest}

The author declares no conflicts of interest regarding the publication of this paper.

\section{References}

[1] Chen, C. (2003) Financial Plan and Capital Control of Real Estate Development Project. Dongnan University, Nanjing.

[2] Luo, J. (2005) Analysis of the Indirect Debt Financing Problems of Real Estate Development. Optimization of Capital Construction, 17, 34-37.

[3] Shi, Y. (2005) Analysis of the Situation of the Real Estate Fund Source in Our Country. China Real Estate, No. 10, 61-62.

[4] Wang, W. (2002) Analysis of Financing Decision in Chinese Real Estate Enterprises. Nanjing University, Nanjing.

[5] Zhang, J. and Zhang, P. (2004) The Research Confirming the Financing Structure of Real Estate Based on AHP. Optimization of Capital Construction, 25, 13-15, 25. 